\title{
Achievers of Freedom in the Select Novels of Rabindranath Tagore
}

\author{
Dr. Silima Nanda
}

M.A, Ph.D.

Deputy Director

Regional Evaluation Centre

Bhubaneswar, Odisha, India

snanda@ignou.ac.in

Dr. Hanny Gandhi

Regional Evaluation Centre

Bhubaneswar, Odisha, India

hannygandhi@yahoo.com

\begin{abstract}
My article analyses the achievers of freedom in the select novels of Tagore who dedicate themselves to the higher ideals of love, self-knowledge and truth. They represent Tagore's vision of freedom where man-made shackles fail to trap the Universal Man. Tagore's idea of freedom begins with the personal and ends with the universal. The different characters in his novels reach different levels of freedom in their search. They struggle as they are faced with challenges, but they all grow. The true achievers analyzed in the select novels of Tagore are the emancipated characters who possess the innate strength to confront the outward challenges of the society and
\end{abstract}


achieve ultimate freedom by transcending from the lower self through love, knowledge and creativity.

Keywords: freedom, universal, ultimate, emancipated, love.

Introduction

Tagore is fondly remembered as a poet, novelist, philosopher, dramatist, actor, composer, teacher, painter et al, but above all these he was a profound humanist and a nationalist with feelings of universal brotherhood. A myriad-minded man, Tagore's concept of Freedom is not only multi-layered but also colossal because it is a curious amalgam of tradition and modernity. Be it education, nationalism, humanism or universalism, all amalgamate proportionately in Tagore's world of complete freedom. His nuanced ideas form an infinite set of concentric circles revolving around the common center of freedom, where despite its own axis, each one overlaps, and without rescinding complements the other. The achievers of freedom discussed in this article dedicate themselves to Tagore's higher ideals of love, self-knowledge and truth.

Who are the Achievers?

The true achievers of freedom are intrepid individuals who are capable of taking audaciously courageous decisions and also stand by them in the midst of crisis. Their journey is a continuous development that leads to what Tagore calls a 'higher freedom' - 'a freedom from all racial and national prejudice." (Gupta, U. p. 25) Achievers personify freedom, synonymous to the emancipation of mind and spirit. It is Tagore's belief that "true modernism is freedom of mind, not slavery of taste; it is independence of thought and action, not tutelage 
under European schoolmasters." (Choudhuri, p. 146) A similar view comes from the Western world where in his famous essay what is Enlightenment? (1784) Immanuel Kant remarks that it is "man's emergence from his self-incurred immaturity...The motto of enlightenment is...Dare to be wise!" (Nisbet, p.1). Tagore created some exceptional characters whose journeys of selfexploration become a source of inspiration for others. Their logical acumen coupled with heroic resistance lead them to the great desideratum - freedom. "He not only wrote about a redemptive social pedagogy, but sought the means to practicalize such visions..." (Bannerji, p. 13). For Anandamoyee and Paresh Babu in Gora and Nikhil in Ghare-Baire freedom is an inseparable part of their identity; "freedom is a consciousness, a consciousness of the being of man." (Mohanty, p. 221). In the select novels of Tagore the achievers exercise their freedom within a given context. While Anandamoyee and Paresh Babu enjoy their freedom in a religious and socio-cultural set up, Nikhil personifies freedom in a more socio-political context, highlighting true nationalism.. Freedom as part of their personality is not only a matter of will but also reason i.e. they have reasoned with their lower self to bring it at par with the true self. Background

During the phase of Renaissance when Bengal society transitioned from the medieval to the modern era. Calcutta being a typical Anglo-Indian cit provided the ideal social and cultural setting for the meeting of the East and West. When the foreign rule mixed its seeds in this rich Bengali soil, it created an educated middle class called the bhadralok, committed to bring social change. Progressive reform movements like Young Bengal, the Brahmo Samaj and later the Tattwabodhini Sabha led to an intellectual awakening, which alarmed the conservative Hindus as questions were raised about the status of women, caste system and other religious orthodoxies. "Through this process Hindu society faced a kind of challenge which it had never felt before. It 
was a challenge as much from without as from within.” (Ahmed, p. 26) During this period, Bengal saw advancement in the field of science as well. Scientists such as J.C. Bose wrote science fiction while P.C. Mahalanobis and S.N. Bose became the pioneers of mathematical physics and quantum mechanics. In the political front, to widen the gap among people, Lord Curzon proposed the partition of Bengal, which proved to be the last straw on the camel's back for disintegrating the Hindu-Muslim unity. This was followed by the tragic communal riots and the Bango Bhango Andolan (anti-partition movement) led by eminent leaders like B.C. Pal, S.C. Bannerjee and Sister Nivedita to name a few. It triggered the Swadeshi era (1905-1911) that enthused a feeling of patriotic nationalism amongst the Bengalis. These movements that advanced the cause of Hindu nationalism allured Tagore and he realized that India must primarily address its social problems, "we in India have...to remove those social customs and ideals which have generated a want of self-respect..." ( Mitra, p. 245) Swadeshi was followed by a call to boycott foreign goods, aimed at restoring the economy of the country. Amidst this Swadeshi fervour the British Raj forbade students from supporting or joining any antigovernment movement. Reacting to the call, students boycotted classes in the Calcutta University describing it as Ghulamkhana, and shouted Bande Matram in the streets. They were in turn beaten up with lathis. Even women students joined such protests and helped in organizing strikes and collecting funds.

Anandmayee : An embodiment of Freedom

The achievers as portrayed against this background of turmoil represent Tagore's mouthpiece advocating change through "reform in the ways of thinking...[for] the great unthinking masses. For this enlightenment...nothing is required but freedom...” (Kant, p. 2) 
These achievers of freedom were not idealistic individuals; their pragmatic approach towards life gave them what P.C. Hogan calls a 'practical identity' i.e. "what we do...in relation to others...and...his or her contribution to collective wellbeing..." (Marsh, p. 12) In Gora, Anandamoyee is a Hindu Brahmin, Paresh Babu is a committed Brahmo but they are "free from religious fanaticism and do not take sides in the heated Brahmo-Hindu conflicts of the day." (Sarada, p. 66) Tagore "sought the ideals of the all-round development of the human being; 'religion of man' constituted for him the basis for religion itself." (Mitra, p. 245) At a time when caste and class divisions generated stereotype roles for women, wife was considered as her husband's shadow, Anandamoyee emerged as "the embodiment of communal identity." (Ibid.) She "plays a pivotal role by influencing, inspiring and guiding all the four major characters in the novel." (Sarada, p. 65) Anandamoyee doesn't figure in the novel for a very long time but she makes her presence felt because of her ideas. She possesses a humanistic vision that loves Binoy and Gora equally though one is a Hindu and the other a Christian. She shuns narrow nationalism and emerges as a mother who embraces universalism, tolerance and cooperation. Even though Gora's entry in her life lands her outside her caste/religion but it also becomes the cause of her release from the fetters of religious casteism. She questions "What is the caste of human heart? It is here that God reconciles all...if we...depend on mantra and ideology to unify people, can it work?" (Gora, p. 229) Anandamoyee is the ideal of Indian womanhood as envisaged by Tagore; she is his "heaven of freedom, where there is no barrier between man and man." (Sarada, p.66)

Although sidelined by people inside the home and outside, Anandmayee remains unfazed by challenges and never allows others to determine her life. The very essence of her being undergoes a change when she adopts Gora. It is as if she adopted universal love and humanism at that very moment, that "shakes the foundations of her belief and gives her a new 
religion.” (Sengupta, p. 210) Krishandayal's neurotic religious orthodoxy makes him avoid any encounter with Gora especially his touch while he also “kept Anandamoyee... at arm's length as a heathen or maleccha. (Gora, p. 143) Krishandayal is exasperated as his wife does not care about social norms declaring, "since I have brought up Gora as my own child, any hypocrisy on my part regarding social rituals would go against my own true religion...I never seek to hide anything...I do not conform to the social regulations and though...I invite hatred from all...I keep mum." (Gora, p. 32) Ironically it is the same Gora who had asked her to dismiss Lachmya (her Christian maid) before he can have food with her because "what is rule is rule; rules must be obeyed by any means." (Gora, p. 15)To this Anandamoyee had given a well-reasoned reply, "nobody in this world is born with a racial identity...if I hate one for being Christian or low class, God will snatch you away from me...I will take my food and drink from members of all races of the world." (Gora, p. 16) Even his extreme disapproval of her choices fails to deter her from her path because she "simply did not have the habit of moulding her action according to the consideration of possible public opinion or reaction." (Gora, p. 220) Though worried about how Gora would take the truth of his birth Anandamayee however remains true to her religion saying, "although I brought you up...I cannot accept what you call 'dharma'. (Gora, p. 16). Her affection for Gora is an "exclusive treasure of her own. She tried to accommodate and make light of Gora's unrightful position in this house in all possible ways." (Gora, p. 207) Anandamoyee's untrammeled freedom to act as per her free will is a source of inspiration for Binoy who admires her courage and non-discriminatory nature. He realizes much before Gora that she is the "epitome of my motherland, let it motivate me to duties and keep me firm in them." (Gora, p. 19-20) He tells her silently, “Ma, no scriptural code can ever convince me that your food is not my nectar." (Gora, p. 20) It is Anandamoyee who is the first to give her consent for Binoy and 
Lalita's marriage. "Through her Tagore points how the barriers of caste, creed, religion and race can be overcome by love and understanding." (Sarada, p. 65). "She believes that human beings are not born with caste and there is no reason why they cannot be united in wedlock in spite of their different religions." (Sarada, p. 66) As opposed to Gora and Sucharita, who follow religion as an external compulsion, Anandamoyee practices her belief internally. Tagore says, "The religion that we get acquainted with from outside...is only a matter of habit. To unfold...religion within oneself is the life-long aspiration of every human soul." (Dutt, p.51) Anandamoyee is open-minded and is against imposing her will on others. She "never forbade anyone to do something on account of her own suffering.... Fear was alien to her nature.” (Gora, p. 145)

By placing Baradasundari alongside Anandamoyee, the author brightens the contrast between the outer display and inner freedom respectively. The former swanks about modernity of the Samaj in all social gatherings but inwardly she is very conservative in her outlook. She thinks that Paresh Babu is inflating "Sucharita's pride...eventually it will be difficult to get a groom for her" (Gora, p. 90) and wants to sacrifice Sucharita's individuality by marrying her off to Haran while Anandamoyee breaks all religious shackles to save Gora. "Tagore's vision of religion and India get merged in the one beautiful composite figure of Anandamoyee." (Ray \& Kundu, p. xix) Sucharita and Lalita are filled with immense admiration for Anandamoyee because of her positive vision towards life. They realize that she is the source through whom Gora and Binoy derive their moral strength. Anandmayee not only adheres to what she believes but also upholds those values. She says, "I obeyed the norms of the society till the day society was greater for me than all...but one day God revealed Himself...in such a way that it was no longer possible for me to obey the rules of the society. When he Himself came and snatched away my caste, then whom have I to fear?” (Gora, p. 267) Her humanistic approach to respect 
the freedom of others is disapproved by all but she remains composed. "It had been her habit all along to absorb all anxiety without fuss. She could accept both happiness and unhappiness calmly; the turbulence of her heart could be perceived only by the omniscient God." (Gora, p. 208) Lalita in Brahmo Samaj is in many ways a revolutionary side of Anandamoyee; both have no place in their respective communities. She feels if "there cannot be any friendship between a Hindu and a Christian...in that case it is better to erect huge walls to keep each community segregated within its own boundaries." (Gora, p. 363) In the end it is Anandamoyee who helps both Sucharita and Lalita, caught between the dichotomies of two communities. She explains that leaving the Samaj or taking initiation are not things that matter because "whether other should accept me or reject me will be up to them...but till the end I shall call my own my own... (Gora, p. 307) It is through Anandamoyee's unconditional love and support that Binoy gains his real freedom. She questions him and the reader too, " if Hindu samaj can accommodate three hundred thirty-three billion shades of ideologies, then why shouldn't your idea too hold as good as others?" (Gora, p. 360) When Lalita's own mother refuses to join her wedding, it's a compassionate Anandamoyee who comes forward saying "I am the bride's party." (Gora, p. 423) "Since she has surrendered all her burden to God, she does not feel any difficulty in carrying the burden of others." (Gora, p. 258) Binoy who had all along remained silent declares emphatically in front of Gora "You have been defeated by your mother, yes, a thousand times over. Where to find another such Ma!' (Gora, p. 436)

A comparative study

We find a similar emancipated woman in Tagore's short story Stree Patra (Letter from a Wife, 1914) where Mrinal, an educated and emancipated woman, frees herself from the shackles of patriarchy leaving behind a letter for her husband describing how everyone in her matrimonial 
house stood against her when she took a stand in favour of Bindu (her sister-in-law's young sister). Bindu is forcefully married to an insane and violent man and she runs away from the house to seek shelter with Mrinal. No one in the house accepts Bindu to stay with them and this denial results in Bindu's suicide. However Bindu's suicide shakes her and Mrinal firmly decides to free her from such a ruthless society that marginalizes woman. Like Tagore, Saratchandra portrays Hemangini a woman of courage in his novel Mejdidi (Middle Sister 1915). She is an emancipated woman who always supports the cause of justice. At a time when women seldom stepped out of the house, she dares to enter the courtroom to testify against her elder brother-in-law who had duped a poor peasant. Her testimony leads to the division of the family property but she stands firm .Later in the novel Hemangini objects to the ill-treatment of Kishan, (elder sister-in-law's step brother) by the whole family. Hemangini could not tolerate this inhumanity. Her husband warns her to leave Kishan to his fate; however Hemangini prefers to leave the house than to leave the young-orphaned boy.

Paresh Babu : achiever of freedom

Another achiever of freedom is Paresh Babu, representing the good side of the Samaj. He is a knowledgeable and broad-minded man whose guardianship for his girls makes him stand apart from other religious zealots in the novel. "Paresh babu's aim is to become one with the cosmic being and so he always aspires after the best and the truest... [as] he had earned an inner freedom..." (Gora, p. 256) Tagore also "interpreted freedom as an extension of individual into cosmic and later into transcendent consciousness..." (Verma, p. 111) Paresh silently protects his children and is strong-willed enough to stand by them whenever they need him. He never imposes his will upon them nor interferes in their decisions. Sucharita and Lalita have deep 
respect for their father and can go to any extent to keep up his honour. Spending most of his time in prayers, he seems "ever humble in reverence to the truth...there was no trace of vulgar show in him...one could feel the sublime nobility of the truth he had been carrying within his own heart." (Gora, p. 93) Paresh Babu represents Tagore's vision of an ideal teacher who selflessly imparts education without clipping the intellectual wings of the taught. He gives them the freedom to use their learning according to their intellect whereas Harimohini's views are that, “excessive studies were unnecessary and harmful for women.” (Gora, p. 333) In 1892 Tagore opined: "When our children are at their growing stage, they should be given proper food for thought...so that their fresh imaginative minds can grow.... dry lessons will deprive them of their imaginative faculty." (Dasgupta, T. p. 150) According to Paresh Babu, "right education came from listening to the opinions of all communities." (Gora, p. 110) And that "girls should mix with people of various opinions and mindsets. Otherwise we enforce a curb on their intelligence." (Gora, p. 56) He believes that caste system generates inequality and hatred leading to all kinds of inhuman atrocities that a man metes out on other men belonging to his race. He sends Sucharita outside the home to see and experience the world saying, “Ma, don't turn to look back, fare forward - don't hesitate. Let anything happen, let anything cross your path; through your capability extract the best from it." (Gora, p. 269) He knows that he cannot be on her side always and protect her from every obstacle, so she has to learn to live on her own. He conveys this parting lesson to Sucharita to inspire her to get out of her conflicting situation -"If you divide yourself into two halves, and give one part to God and the other to something else...things will become difficult for you." (Gora, p. 269)) Gora is utterly displeased with Binoy's marriage to a Brahmo girl. He tries to dissuade Paresh Babu saying, "First we have to obey the society completely in all respects; only then we can attain a clarity of perception 
regarding its purpose." (Gora, p. 406) Though Gora's blunt refusal to join Binoy's marriage shocks Paresh Babu, he calmly says, "I respect the individual freedom of man. It is by testing against that freedom...that we can come to know which is perennial truth and which is temporal assumption...the welfare of the society depends upon that knowledge." (Gora, p. 406) In the entire novel only Anandamoyee and Paresh Babu make no moral judgment on the union of Binoy and Lolita despite their differences in religious beliefs. According to Paresh babu , "There is no entrance route to Hindu society... This society is not a society for all humans; it is only for those who are born into it by chance or a stroke of destiny." (Gora, pp. 416-17) .When everyone turns against Sucharita and her decision to follow Hinduism for Harimohini's sake, only Paresh Babu stands strongly besides her. He curtly tells Haran that, “... If she had been drowning, I should be the first person to know it and the last to remain indifferent." (Gora, p. 243) He supports Lalita too and is not misled by the scandalous rumour about her even when the whole Brahmo community stands against him.

Tagore has symbolically conveyed to the readers about the traits of the achievers of freedom in Gora's epiphany, leading him to Pareshbabu and Anandamoyee. His freedom first lands him before Pareshbabu, the universal man as Gora asks him, 'Do you know why I have rushed to you and you alone immediately on attaining freedom?'Paresh says, 'Why?'

Gora tells, 'You alone know the mantra of this freedom.

That is why you have no place today in any society. You make me your disciple. You teach me the mantra of that God, who is the god of all - be they Hindu, Musalman, Christian, Brahmo and whatever else... the God of Bharatbarsha!' (Gora, p. 471) 
An enlightened Gora reaches out to his mother and tells her "It is you who is my Bharatbarsha..." (Gora, p. 472).

Nikhil : The Humanist

Nikhil a humanist to the core in Ghare Bairey "has too much of Tagore in him, [he] is emblematic of all good... [and] remains calm, gentle, understanding, forgiving, liberal, rational and altruistic throughout the novel..." (Quayum) He is a highly educated zamindar and does not follow the lavish ways of typical aristocrats. A member of an evolving Bengali modernity, he marries Bimala, an ordinary looking girl of humble roots. He believes in the equality and freedom of all human beings and encourages her to learn the modern Western mannerisms alongside her traditional lifestyle. He does not let her worship him and instead goads her to experience the outer world. Mahendra in Chokher Bali is the opposite of Nikhil who confines his wife Asha and does not mind crushing her freedom. Like Tagore, Nikhil believes that real freedom comes through awakening the people from their deep slumber of ignorance. A supporter of peaceful economic reconstruction, Nikhil does not endorse the way Swadeshi youth spread their message. The Swadeshi being an elitist movement was imposed upon the poor peasantry as an added burden and they were made to shun imported goods by force. Nikhil feels, "if fear is to regulate how people are to dress, where they shall trade, or what they must eat, then man's freedom of will is utterly ignored and manhood destroyed at the root." (Ghare-Baire, chp. x) He wants to eradicate hunger and misery from his country and tells Bimala: "Let us dedicate our lives to removing the root of this sorrow in our country." (Ghare-Baire) His compassion for the poor especially for Panchu who is asked to pay fine and receives beating from the Swadeshi youth is looked down upon as an act of betrayal by the Swadeshi youth but he does not explain. 
Instead he tells them, "You have been so used to submit to domination, you have come to believe that to make others submit is a kind of religion." (qtd. in Mitra, p. 249). Nikhil's love for the motherland takes a practical shape in buying swadeshi and also giving employment to many others in the job of weaving. He believes that, "We must not seek the help of illusions...for what we believe to be the true cause." (Ghare-Baire, Chp. ix). Nikhil and Sandip represent two extreme visions of nationalism - the former stands for reconstruction while the later upholds revolution. In Pather Dabi (The Right of Way, 1926) Saratchandra's hero Sabyasachi Mallik like Nikhil,is against caste system and the rich-poor divide.. He desires to o eliminate "all that is eternal, ancient and decaying...[in] religion, society, tradition...[being] enemies of nation." (Chatterjee, p. 165)

Nikhil as a reformist supported individual freedom and woman emancipation. To his wife he says, "I tell you, truly, Bimala, you are free. Whatever I may or may not have been to you, I refuse to be your fetters." (Ghare-Baire, chp. xi) He considers Bimala as his equal in all respects. To curb her individuality is for him the biggest sin. He tells her "Merely going on with your household duties, living all your life in the world of household conventions and the drudgery of household tasks--you were not made for that! If we meet, and recognize each other, in the real world, then only will our love be true." (Ghare-Baire, p. 8) The dichotomy of the home and the world depicts the polarity between Nikhil and Sandip where Bimala is struck between the two extremes. Nikhil does not want to impose his ideas in her mind while Sandip believes in coercive methods. For Nikhil, freedom is not something that can be given and taken externally; hence Bimala searches for freedom internally. "Nikhil's vision is one of enlightened humanitarian and global perspective, based on a true equality and harmony of individuals and nations." (Quayum) "In the figure of Nikhil...Tagore projects...his personal occupation with the individual freedom 
to choose his way of serving the cause of social and political emancipation'." (Mitra, p. 245) Tagore exposes the hypocrisy of the Swadeshi movement through Sandip's character, the revolutionary orator who preaches nationalism but has "as immense an attraction for foreign medicine as the earth has for meteors." (Ghare-Baire, p. 17) The author validates Nikhil's strength of character who knows he is being cheated but does not try to curb the freedom of others. As an achiever of freedom, Nikhil may not have successfully saved his country from the evils of religious or communal bigotry but he fervently tries to make Bimala realize the true freedom that she had been denying herself in nine years of her married life. He declares, "It is my desire...to plant something greater than Swadeshi. I am not after dead logs but living trees and these will take time to grow." (Ghare-Baire, chp. x). Anandamoyee, Paresh Babu and Nikhil truly represent Tagore's philosophy of being the true achievers of freedom. These selfgoverned and rational individuals possess exceptional virtues of love, truth and goodness, knowledge and creativity that stand the test of time. Their emancipation is a source of inspiration for others. In the author's own words:

The first stage towards freedom is the Santam, the true peace, which can be attained by subduing self; the next stage is the Sivam, the true goodness, which is the activity of the soul when self is subdued; and then the Advaitam, the love, the oneness with all and with god...we must know is that the santam, sivam, advaitam, is the only goal for which we live and struggle. (The English Writings, 2007: p. 319) 
Conclusion:

Thus believing in the spiritual evolution of man, Tagore emphasized that "stress on the inner transformation of man to solve the problems of the modern world.” (Chakravorty, p. 256) While Anandamayee "is the microcosmic representation of that macrocosmic India of Tagore's vision, at whose feet the 'great ocean of humanity' can gather, because she can reach out to, and embrace all religions and nationalities through her all absorbing love.” (Ray \& Kundu, p. xix) Paresh Babu devotes himself to the knowledge of the infinite. It is Tagore's philosophy that one gets to know the infinite through the finite. Being at peace with himself, he refuses to be defeated by the outer forces. The same stands true for Nikhil who believes that real freedom would be awakening the people from their deep slumber of ignorance. The achievers analyzed pave the path towards transcendence from the lower self that is realized through love, knowledge and creativity. Each character entering this domain gets an exclusive (although limited) human perception of it, because freedom is truly infinite. Tagore believes, "that in the human world only a perfect arrangement of interdependence gives rise to freedom...the history of the growth of freedom is the history of the perfection of human relationships." (Verma, p. 117). For Tagore, an individual's true realization is in the recognition and understanding of others. Thus “Rabindranath Tagore's personality was a fusion of power and purity, of sweetness and ligh ..... He was an annadamaya purusha, a Realised Sage and the Complete Man.” (Nandakumar, p. 31) 


\section{References:}

Ahmed, A.F. Salahuddin. Social Ideas and Social Change in Bengal 1818-1835. Netherlands: Leiden E.J. Brill, 1965. Print.

Bannerji, Himani. Always Towards: Development and Nationalism in Rabindranath Tagore. Kolkata: Institute of Development Studies Kolkata, 2008. Print.

Casci, Simonetta. "Nationalism and Gender Ideology in Bengali Literature.” II Politico, Vol. 64, No. 2 (189), 1999, pp. 277-291. Website. JSTOR, www.jstor.org/stable/43101881. Retrieved on 27/02/2019.

Chakravorty, B.C. Rabindranath Tagore: His Mind and Art. Young India Publication: New Delhi, 1971. Print.

Chatterjee, Joya. Bengal Divided: Hindu Communalism and Partition, 1932-1947. Cambridge South Asian Studies (No. 57): Cambridge, 2002. Print.

Choudhuri, Indra Nath. "Tagore and Gandhi: Their Intellectual Conflict and Companionship." Indian Literature, Vol. 59, No. 2 (286), 2015, pp. 146-157. Website. JSTOR, www.jstor.org/stable/44478532. Retrieved on 22/09/2018.

Dasgupta, Tapti. Social Thought of Rabindranath Tagore: A Historical Analysis. Abhinav Publications: New Delhi, 1993. Print.

Dhar. Banshi. "The Humanism of Rabindranath Tagore." Indian Lietrature, Vol. 16, No. 1/2, 1973, pp. 147-152. Website. JSTOR, www.jstor.org/stable/24157437. Retrieved on $26 / 01 / 2019$

Dutt, Indu. Trans. A Tagore Testament. Bombay: Jaico Publishing House, 1969. Print. 
Gupta, Uma Das. "In Pursuit of a Different Freedom: Tagore's World University at Santiniketan.” India International Centre Quarterly, Vol. 29, No. 3/4, 2002, pp. 25-38. Website. JSTOR, www.jstor.org/stable/23005814. Retrieved on 22/05/2020.

Kant, Immanuel. What is Enlightenment? Konigsberg, Prussia: Berlinische Monatschrift, November 1784. pp. 1-4. Website. url: la.utexas.edu/users/hcleaver/330T/350kPEEKantEnlightenment.pdf. Retrieved on $15 / 03 / 2020$.

Kumar, Dr. Raj, ed. History and Culture Series: Essays on Social Reform Movements. New Delhi: Discovery Publishing House (DPH), 2004. Print.

Marsh, Christine. "Rabindranath Tagore: Critic of Enlightenment." Asiatic, Vol. 7, No. 1, United Kingdom: University of Exeter, June 2013, pp. 1-16. Print.

Mitra, Indrani. "I Will Make Bimala One With My Country: Gender and Nationalism in Tagore's The Home and the World." Modern Fiction Studies, Vol. 41, No. 2 (Summer 1995), pp. 243-264. The John Hopkins University Press. Website. JSTOR, www.jstor.org/stable/26285526. Retrieved on 23/01/2019.

Mohanty, Prafulla Kumar. Freedom as Identity: The Literature of Rising. Indian Literature, Vol. 53, No. 1 (249), 2009, pp. 220-228. Website. JSTOR, www.jstor.org/stable/ 23348507. Retrieved on 22/02/2019.

Nandakumar, Prema. "Tagore and Bharati.” Indian Literature, Vol. 12, No. 1, 1969, pp. 31-39. JSTOR, www.jstor.org/stable/23329115. Retrieved on 20/03/2020.

Nisbet, H.B. trans. An Answer to the Question: 'What is Enlightenment?' Immanuel Kant. New Delhi: Penguin, 1991. Print. 
Quayum, Mohammad. "Ghare Baire”. The Literary Encyclipedia. 22 April 2005. Website. www.litencyc.com/php?rec=true \&UID=16758. Retrieved on 24/01/2019.

Radhakrishnan, S. The Philosophy of Rabindranath Tagore. Macmillan: London, 1919. Print.

Ray, Mohit K., Rama Kundu, trans. Gora. Rabindranath Tagore. New Delhi: Atlantic, 2008. Print.

Sarada, M. Rabindranath Tagore: A Study of Women Characters in His Novels. New Delhi: Sterling Publishers, 1988. Print.

Sengupta, S.C. The Great Sentinel: A Study of Rabindranath Tagore. Calcutta: A. Mukherjee, 1948. Print.

Tagore, Rabindranath. Ghare-Baire. London: Macmillan, 1919. Website. Www.gutenberg.org/ebooks/7166 Ebook \#7166: December 2004.

Tagore, Rabindranath. Binodini. New Delhi: Sahitya Akademi Rev. ed.1968. Print.

Ibid Chokher Bali. Trans. Sukhendu Ray. New Delhi: Rupa, 2004. Print.

Ibid Ghare-Baire.Trans, Surendranath Tagore. London: Macmillan, 1919. Website: www.gutenberg.org/ebooks/7166 Ebook \#7166: December 2004.

Ibid. Gora. Trans. Ray, Mohit K., Rama Kundu. New Delhi: Atlantic, 2008. Print.

Ibid. Chaturanga, trans. Ashok Mitra, New Delhi: Sahitya Akademi, 1963.

Tagore, Rabindranath. Gora. Trans. Ray, Mohit K., Rama Kundu. New Delhi: Atlantic, 2008. Print.

The English Writings of Rabindranath Tagore. Vol. Six. Essays, Lectures, Addresses. New Delhi: Atlantic, 2007. Print.

Verma, Vishwanath Prasad. “Shri Aurobindo's Concept of Freedom and Western Political Idealism: A Reconstruction and Comparative Study." The Indian Journal of Political 
Science, Vol. 17, No. 2, 1956, pp. 105-134. Website. JSTOR, www.jstor.org/stable/42743642. Retrieved on 26/01/2019. 